\title{
Paraophioidina scolecoides n. sp., a new aseptate gregarine from cultured Pacific white shrimp Penaeus vannamei
}

\author{
Timothy C. Jones ${ }^{1}$, Robin M. Overstreet ${ }^{1,{ }^{*}}$, Jeffrey M. Lotz ${ }^{1}$, Paul F. Frelier ${ }^{2}$ \\ ${ }^{1}$ Gulf Coast Research Laboratory, PO Box 7000, Ocean Springs, Mississippi 39566, USA \\ ${ }^{2}$ Department of Veterinary Pathobiology, College of Veterinary Medicine, Texas A\&M University, College Station, \\ Texas 77843 , USA
}

\begin{abstract}
The aseptate gregarine Paraophioidina scolecoides n. sp. (Eugregarinorida: Lecudinidae) heavily infected the midgut of cultured larval and postlarval specimens of Penaeus vannamei from a commercial 'seed-production' facility in Texas, USA. It is morphologically similar to $P$. korotneffi and $P$. vibiliae, but it can be distinguished from them and from other members of the genus by having gamonts associated exclusively by lateral syzygy. Shrimp acquired the infection at the facility; nauplii did not show any evidence of infection, but protozoea, mysis, and postlarval shrimp had a prevalence and intensity of infection ranging from 56 to $80 \%$ and 10 to $>50$ parasites, respectively. Infected shrimp removed from the facility to aquaria at another location lost their gamont infection within $7 \mathrm{~d}$. When voided from the gut, the gregarine disintegrated in seawater. Results suggest that $P$. vannamei is an accidental host, although a survey of representative members of the invertebrate fauna from the environment associated with the facility failed to discover other hosts. No link was established between infection and either the broodstock or the water or detritus from the nursery or broodstock tanks.
\end{abstract}

KEY WORDS: Gregarine - Parasite - Paraophioidina scolecoides n. $\mathrm{sp}$. 'Shrimp - Penaeus vannamei . Aquaculture

\section{INTRODUCTION}

Gregarines are a diverse and successful group of protozoan parasites belonging to the phylum Apicomplexa. The largest order within the subclass Gregarinasina Dufour, 1828 is Eugregarinorida Léger, 1900. In this order, there are 2 large suborders, the members of which are distinguished morphologically by the number of body divisions (Levine 1976). Gamonts of members of Aseptatorina Chakravarty, 1960 are composed of a single compartment, but for those in Septatorina Lankester, 1885 gamonts are divided into 2 distinct compartments.

Gregarines are parasites of the intestine or body cavity of invertebrates, particularly arthropods (Manwell

\footnotetext{
- Addressee for correspondence
}

1977). Septate members are common intestinal parasites of both natural and cultured shrimp (Kruse 1959, Overstreet 1973, Lightner 1993). In particular, the genera Cephalobus Kruse, 1959 and Nematopsis Schneider, 1982 have a worldwide distribution in cultured penaeids (Lotz \& Overstreet 1990, Lightner 1993). There is concern that heavy infection with these gregarines has the potential to cause economic losses through host mortality and reduced growth of the host in ponds (Lightner 1993). In shrimp aquaculture, however, gregarines are rarely seen in 'seed' (= postlarvae) production. In this paper, we describe a new species of Aseptatorina that infects the midgut of larval and postlarval specimens of Penaeus vannamei and report on aspects of the protozoan's biology, factors that had economical implications for a commercial seed-production facility in Texas, USA. 


\section{MATERIALS AND METHODS}

Terminology. We use the term 'gamont' collectively to describe gregarines attached to host gut cells, free in the lumen, in syzygy or in multiple associations and not just as paired cells in syzygy (Shrével \& Philippe 1993).

Parasite observations. Infected larval and postlarval specimens of Penaeus vannamei were shipped live from the Texas production facility to the Gulf Coast Research Laboratory (GCRL) and to the Texas Agricultural Experimental Station (TAES). At GCRL, the guts of infected shrimp were removed with fine forceps and placed on glass slides in $0.85 \%$ saline for microscopic examination of gregarines at 100 or $200 \times$. Closer examination required teasing of individual gamonts from the midgut for photography and occasional fixation in Davidson's fixative (Humason 1972). Fixed specimens of whole larval and postlarval shrimp stored in $70 \%$ ethanol were embedded in paraffin blocks, sectioned at $4 \mu \mathrm{m}$, and stained in Gill's hematoxylin and eosinphloxine. At TAES, similarly fixed nauplii were embedded in epon and stained with toluidine blue.

Life history studies. A total of 15 to 20 shrimp from each consignment of nauplii ( 3 and 5 d old), protozoea ( $8 \mathrm{~d}$ old), mysis (10 d old), and postlarvae $(15,16$ and $21 \mathrm{~d}$ old) of Penaeus vannamei were received at GCRL and immediately processed for histological assessment as described above. Shrimp were maintained with minimal water changes in $38 \mathrm{l}$ aquaria at $28 \mathrm{ppt}$ salinity and $26^{\circ} \mathrm{C}$. A sample of 25 larval or postlarval shrimp was examined as wet mounts for gregarines daily for the first $10 \mathrm{~d}$ postreceipt and weekly thereafter. Nauplii, protozoea, and mysis were observed over a $31 \mathrm{~d}$ period while postlarval shrimp 15, 16 and $21 \mathrm{~d}$ old were examined up to $86 \mathrm{~d}$. The intensity and prevalence of infection was determined for each shrimp group. Immediately on receipt at TAES, approximately 100 nauplii (4 d old) and 1131 postlarvae (21 d old) from the Texas facility were processed similarly for histological assessment.

We followed in detail the loss of gregarine infections from 6 heavily infected postlarvae $(21 \mathrm{~d}$ old $)$ which were isolated in a $40 \mathrm{~mm}$ glass petri dish filled with 27 ppt seawater. Gamonts observed under a dissecting microscope were monitored for their movements at 12 , $22,25,27$ and $28.5 \mathrm{~h}$.

Source of gregarine infection. Broodstock feces and detritus taken from the maturation and larval rearing systems were tested to determine if either was the source of infection by exposing uninfected shrimp to the material. Two $600 \mathrm{ml}$ plastic bottles containing detritus and a plastic bag filled with $600 \mathrm{ml}$ of seawater and broodstock feces were shipped to GCRL. The samples were shaken for $30 \mathrm{~s}$ and individually dispensed into 3 of 4 (fourth tank served as a control) 38 l aquaria at $28 \mathrm{ppt}$ and $27^{\circ} \mathrm{C}$. Approximately 180 gregarine-free larval shrimp ( $7 \mathrm{~d}$ old) provided by The Oceanic Institute, Makapuu Point, Hawaii, were added to each of the 4 aquaria. Shrimp were fed brine shrimp (Aquarium Products, Glen Burnie, MD, USA) and pelleted commercial feed (Rangen Inc, Buhl, ID, USA). Daily samples of 5 shrimp were removed from each tank and examined as fresh wet mounts for gamonts for $32 \mathrm{~d}$.

We investigated broodstock as a potential source of infection by examining 2 male broodstock sent from the Texas facility. The shrimp were chilled at $-4^{\circ} \mathrm{C}$ for 10 min and dissected. Fresh preparations of gill, midgut, hindgut, and coelomic fluid were examined for the presence of gamonts, gametocysts or spores. An additional 5 broodstock were examined by staff at the Texas facility.

We surveyed the Texâs fachility envir onmen fur villue potential hosts and sources of infection. Water and detritus samples were taken from the broodstock holding raceway, nursery tanks, maturation tanks, biofilters from both the nursery and broodstock systems, main storage tank and external holding pond. Each sample was examined for parasitic life-stages, and invertebrates were removed for additional observation under the compound microscope; large organisms were teased apart using forceps, and small specimens were examined whole.

Coccidiostat experiments. At TAES, the efficacies of 4 coccidiostats for treatment of infections with Paraophioidina scolecoides were tested with infected postlarvae of Penaeus vannamei. The 4 coccidiostats were administered orally in poultry feed to 5 groups of postlarvae ( 16 to $21 \mathrm{~d}$ old). Each group had 2 replicates so that 2 control replicates received feed without drugs, 2 replicates each received either Elancoban-100 ${ }^{\circledast}$ or Bovatec $^{(1)}$ at a dose of $1.66 \mathrm{~g} \mathrm{~kg}^{-1}$ of feed, and 2 groups each received either Rofenaid ${ }^{\circledast}$ or Monteban ${ }^{\oplus}$ at $92 \%$ of the high poultry dose. After $6 \mathrm{~d}$, selected shrimp were removed from each group and examined histologically for evidence of infection.

\section{DESCRIPTION}

\section{Paraophioidina scolecoides n. sp. (Figs. 1 to 6)}

Diagnosis: Apicomplexa, Eugregarinorida, Aseptatorina, Lecudinidae Kamm, 1922, with elongate, aseptate gamont. Gamont with truncated anterior mucron Nucleus spherical to ovoid with central nucleolus nucleus located in anterior third of the body. Syzygy lateral, often involving multiple associations. Movement by gliding. Parasitic in Crustacea

Description: Two forms of gregarine gamonts were recovered from the midgut and hindgut (Figs. 1 \& 2) (1) The immature gamont was aseptate, translucent, 

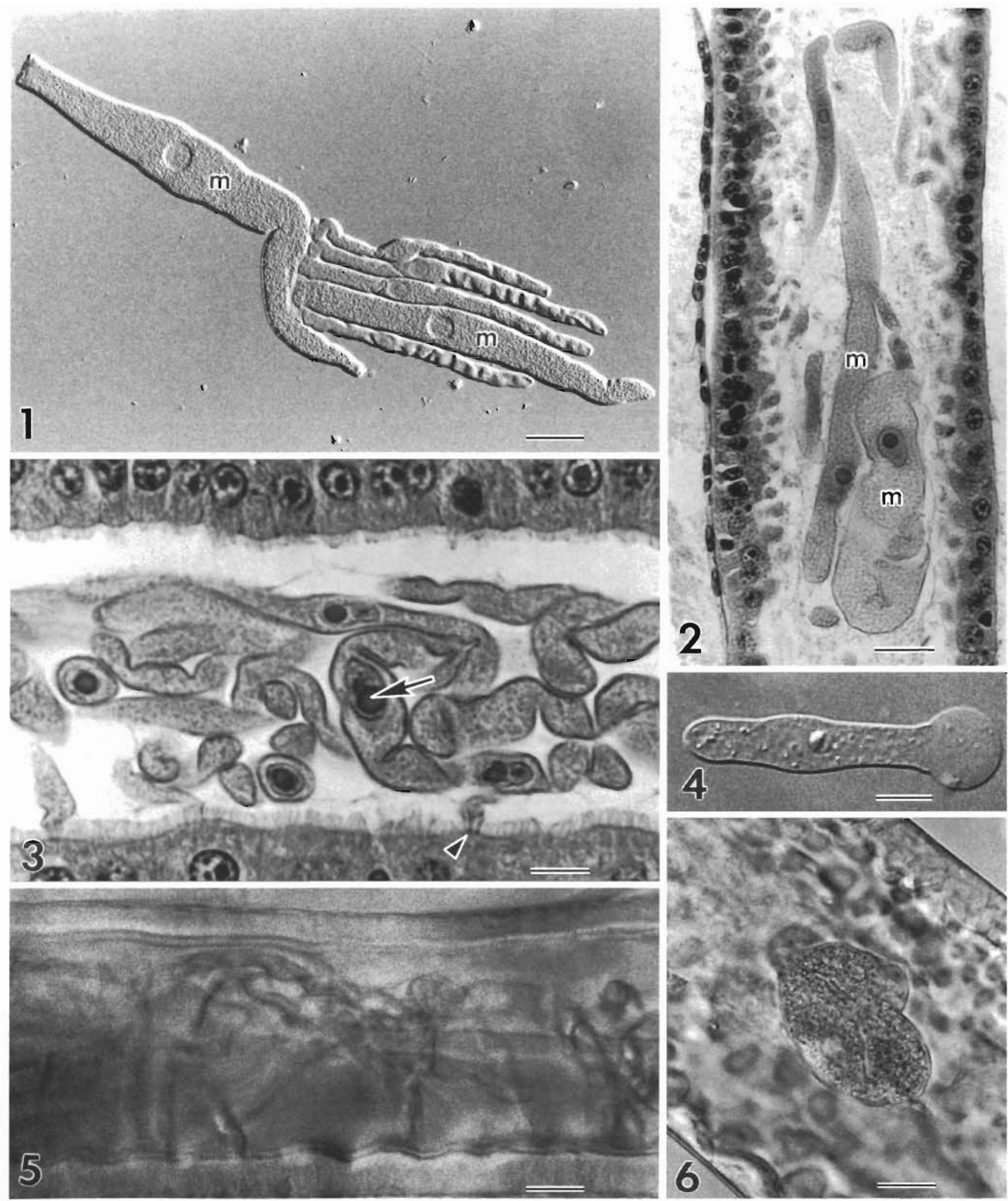

Figs. 1 to 6. Paraophioidina scolecoides n. sp. infectıng Penaeus vannamel. Fig. 1. Multıple associatıon of mature and ımmature gamonts in midgut of infected postlarva showing 2 mature gamonts (m) and 4 immature gamonts. Fresh preparation, by Nomarski, scale bar $=50 \mu \mathrm{m}$. Fig. 2. Midgut of postlarva containing gregannes, mature $(\mathrm{m})$ and immature gamonts. H\&E, scale bar $=50 \mu \mathrm{m}$. Fig. 3. Midgut of postlarva heavlly infected with gamonts. Some gamonts superficially attached to midgut wall (arrowhead); note good condition of the epithelium, intact brush border, and parasite nucleolus (arrow) within nucleus. H\&E, scale bar $=10 \mu \mathrm{m}$. Fig. 4. Disintegrating gamont in seawater Fresh preparation, unstained, Nomarski optıcs, scale bar $=50 \mu \mathrm{m}$. Fig. 5. Midgut of postlarva with gamonts attached to wall and free in lumen Fresh preparation, by Nomarsk1, scale bar $=100 \mu m$.

Fig. 6. Rounded form of mature gamont in midgut. Fresh preparatıon, by Nomarskı, scale bar $=50 \mu \mathrm{m}$ 
and elongate, measuring up to $200 \times 10 \mu \mathrm{m}(\mathrm{N}=10)$. The posterior end was bluntly rounded. The anterior end was truncated and possessed a flattened mucron. The single nucleus was spherical to ovoid (3.4 to $5.6 \mu \mathrm{m}$ diameter $)$, with a spherical nucleolus $(2.3 \mu \mathrm{m}$ diameter). The nucleus was located one-third of the body length from the anterior end and accounted for one-half the body's total width. Movement was by gliding. (2) The mature gamont was also aseptate, but it contained numerous refractile granules that gave the gamont a brownish color. The mature gamont was 300 to $560 \mu \mathrm{m}$ long by 25 to $45 \mu \mathrm{m}$ wide $(\mathrm{N}=10)$. The posterior end was more rounded than the sharply truncated anterior end. The nucleus was spherical to ovoid (3.9 to $8.2 \mu \mathrm{m}$ in diameter) and contained a spherical nucleolus (average $3.4 \mathrm{\mu m}$ diameter). The nucleus was positioned one-third of the body length from the anterior end and comprised one-half of the total body width.

We did not observe gametocysts or intraepithelial stages in either histological preparations or fresh smears of the shrimp midgut. Only gamonts were observed, and they were found in 3 states: solitary, in syzygy, or in multiple associations of from 3 to 6 gamonts. Occasionally mature gamonts were observed in a rounded form within a thin membrane (Fig. 6).

Syzygy was observed as lateral only; syzygous pairs were composed of mature specimens only, but larger associations included up to 6 gamonts with both mature and immature forms (Fig. 1). Attachment between gamonts was simple rather than by a ball and socket union, and in all associations the satellite was attached to the primite by the mucron. Both mature and immature gamonts were observed free in the lumen or attached to the gut epithelium, both in histological sections (Fig. 3) and in fresh preparations (Fig. 5).

Type host: Penaeus vannamei Boone, 1931; larval and postlarval stages.

Site: Midgut, rarely in hindgut.

Type locality: Southern Texas, USA; commercial shrimp facility.

Material deposited: Syntypes National Museum Parasite Collection, USNM Helm. Coll. no. 83746 ('gamonts' infecting mysis and postlarval specimens in vial $_{i}$ histological section of infected shrimp). Additional syntype material: H.W. Manter Laboratory, University of Nebraska State Museum, HWML no. 37373-37375 ('gamonts' infecting mysis and postlarval specimens in vial; histological section of infected shrimp) and Gulf Coast Research Laboratory Museum no. 1315. All material collected 28 May 1993.

Etymology: The Greek name scolecoides, meaning 'worm-like', refers to the appearance of the living, moving gregarine.
Taxonomic remarks: Levine (1977) established Paraophioidina Levine, 1977 to accommodate elongate gregarines that were both parasitic in crustaceans and lacked a ball and socket association in syzygy. We place $P$. scolecoides in that genus on the basis of Levine's criteria and on the form of the mature gamont. Gamonts of species of the related genera Lankesteria Mingazzini, 1891, Monocystella Valkanov, 1935, and Ascogregarina Ward, Levine \& Craig, 1982 are elongate but spatulate in form, and they are much wider than the thin gamonts described for species of Paraophioidina. Some species of Lecudina Mingazzini, 1891, L. pherusae Levine, 1974, L. polymorpha Shrével, 1969, and L. arabellae Hoshide, 1958 resemble the long, thin form of $P$. scolecoides. However, these species can be differentiated from $P$ scolecoides by having a gamont with smooth (rather than sinuous), parallel, elongate, lateral margins and with a rounded mucron and cytoplasm differentiated into ectoplasm and endoplasm.

Gamonts of Paraophioidina scolecoides can be easily distinguished from all described members of the genus Paraophioidina except 3 species: P. eucopiae (Théodoridès \& Desportes, 1975), P. korotneffi (Théodoridès \& Desportes, 1975), and $P$. vibiliae (Théodoridès \& Desportes, 1972). Théodoridès \& Desportes (1972, $1975)$ originally placed those species in Ganymedes Huxley, 1910, until Levine (1977) transferred them to the genus Paraophioidina. The gamont of $P$. scolecoides appears closest to that illustrated for P. korotneffi by Théodoridès \& Desportes (1975). This latter species is parasitic in the gut of the sergestid shrimp Sergestes robustus, but both species share similar dimensions and a truncated mucron. In both species, the nucleus is located one-third of the body length from the anterior end, and the vacuolated anterior cytoplasm of $P$. korotneffi reported by Théodoridès \& Desportes (1975) resembles the granular appearance that we observed in mature gamonts of $P$. scolecoides. p. korotneffi from France has caudofrontal rather than lateral syzygy.

The gamonts of Paraophioidina vibiliae and $P$. scolecoides are similar in both form and size, and both exhibit lateral syzygy involving gamonts of different size (Théodoridès \& Desportes 1972). However, $P$. vibiliae also exhibits caudofrontal syzygy, and its nucleus is located farther anteriorly than in P. scolecoides. $P$. eucopiae can be distinguished from the Texas gregarine by its sac-like immature gamonts $(60$ $\times 20 \mu \mathrm{m})$ and also by its more centrally located nucleus (Théodoridès \& Desportes 1975). These authors did not report the mode of syzygy displayed by $P$. eucopiae.

The multiple associations formed by gamonts of Paraophioidina scolecoides are unique among Eugregarinorida. Shrével \& Philippe (1993) reported 2 cate- 
gories of associations. The first contains $Y$-shaped associations in which 3 similarly sized gamonts attach by their posterior ends as for Selenidium pendula Giard, 1884 (see Shrével 1971) or in which 2 or 3 relatively small gamonts attach by their anterior end to the posterior end of a larger gamont as for Gregarina blaberae Frenzel, 1892 (see Shrével \& Philippe 1993). The second category involves multiple associations of a linear nature in which several gamonts align in a chain as for G. blaberae (see Shrével \& Philippe 1993) and Didymophyes gigantea von Stein, 1848 (see Hildebrand \& Vinckier 1975).

Host specificity in gregarines is usually strict (Shrével \& Philippe 1993), and, according to Levine $(1976,1977)$, host taxon is used to distinguish many genera of Lecudinidae Kamm, 1922. Members of the genus Lecudina Mingazzini, 1891 are parasitic in Polychaeta (Levine 1976), those of Lankesteria Mingazzini, 1891 are parasitic in Urochordata, those of Ascogregarina Ward, Levine \& Craig, 1982 (previously as Ascocystis Grassé, 1953) are parasitic in Insecta, those of Monocystella Valkanov, 1935 are parasitic in Turbellaria, and those of Paraophioidina are parasitic in Crustacea (Levine 1977). The natural host for the Texas gregarine is probably some crustacean other than Penaeus vannamei, possibly an estuarine one.

\section{RESULTS}

\section{Case history}

In April 1993, larvae of Penaeus vannamei in the larval rearing section of a commercial seed-production facility in Texas became infected with a gregarine in the midgut and hindgut. Shrimp first exhibited the infection at their second protozoeal stage, after they were transferred from the maturation system to the larval rearing system and after they had begun to feed actively. Larval and postlarval shrimp appeared equally susceptible to infection, and staff at the facility noted fluctuations in the prevalence and intensity of gamonts both within and among successive cohorts of shrimp. Prevalence of the gregarine infection in post. larval shrimp maintained in the larval rearing system fluctuated over time, but the infection did not disappear (Fig. 7). We investigated shrimp from the facility periodically until June 1993, at which time larval rearing was halted and water supply systems were drained, disinfected and dried. Infections did not recur when production was resumed, at least not within a 5 mo period after the larval rearing activities were restarted and shrimp were examined. Earlier attempts to eliminate the infection by treating the water supply systems only were unsuccessful.

\section{Life cycle}

Histological preparations and fresh smears of the gregarine in whole larval and postlarval shrimp revealed gamonts only, with no intracellular stages or gametocysts. Overall, a total of 650 nauplii, 475 feeding larvae and 1175 postlarvae of Penaeus vannamei were examined in fresh smears at GCRL. Nauplii of $P$. vannamei ( 3 and $5 \mathrm{~d}$ old) were not infected with gregarines upon receipt from the Texas production facility, and they did not become infected when reared to postlarvae at GCRL. In all other groups of larval and postlarval shrimp received from the Texas facility, the prevalence of gregarine infection declined over time (Table 1). The rate at which shrimp lost infections was the same for all stages (Fig. 7) and could be described by the equation $Y=1.59 e^{-0.82 X}$ as fit by the method of least squares (Wilkinson et al. 1992). Considering all host life stages (excluding nauplii), we calculated the rate of loss of infection as $44 \%$ per day. Protozoea and mysis with a moderate infection of 10 to 50 gamonts per shrimp $(N=10)$ when received became free of the parasite after $4 \mathrm{~d}$. Shrimp obtained as infected protozoea were examined for $31 \mathrm{~d}$, but those obtained as mysis died after $6 \mathrm{~d}$. Moderately infected (10 to 50 gamonts) postlarvae ( $\mathrm{N}=10,15 \mathrm{~d}$ old $)$ were free of gamonts $2 \mathrm{~d}$ after receipt. These shrimp did not become reinfected or otherwise exhibit gregarines when maintained in the same water for up to $86 \mathrm{~d}$. Two

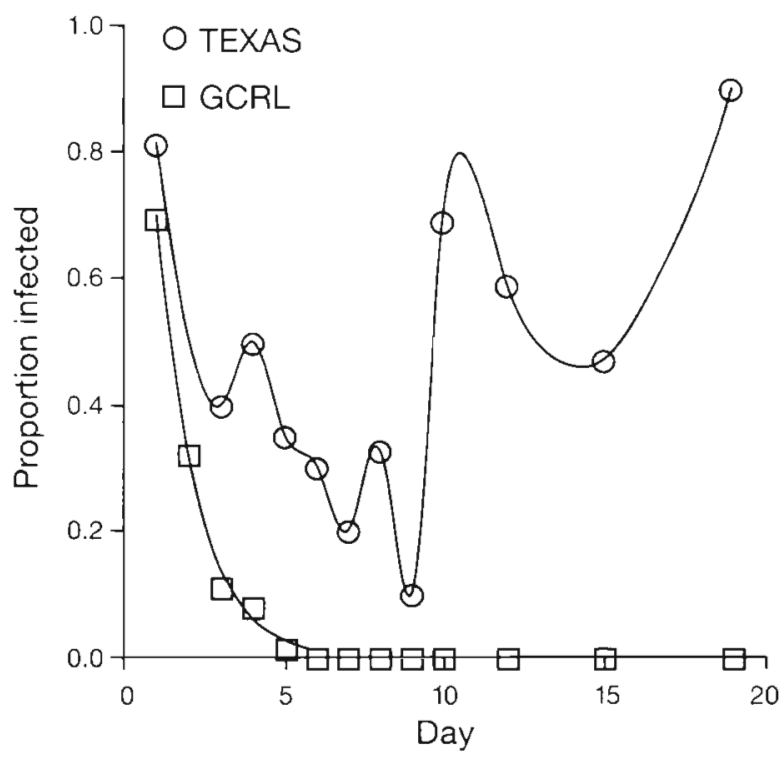

Fig. 7. Differences in proportion of Penaeus vannamei infected with Paraophioidina scolecoides when maintained through larval development at the Gulf Coast Research Laboratory (GCRL) compared to that in larval rearing tanks at a commercial facility (Texas) 
Table 1. Prevalence of Paraophioidina scolecoides in larval and postlarval groups of Penaeus vannamei received from a Texas production facility and maintained at the Gulf Coast Research Laboratory. N3, N5: third and fifth naupliar substages; PZ3: third protozoeal substage; M2: second mysis substage; PL4, PL5, PL10: fourth, fifth and tenth postlarval substages. N: no. of infected shrimp in sample of $25 \%$ : prevalence of infected shrimp

\begin{tabular}{|c|c|c|c|c|c|c|c|c|c|c|c|c|c|c|}
\hline \multirow{3}{*}{$\begin{array}{c}\text { Days } \\
\text { postreceipt }\end{array}$} & \multicolumn{14}{|c|}{ Substage of shrimp upon receipt (age in days in parentheses) } \\
\hline & \multicolumn{2}{|c|}{ N3 (3) } & \multicolumn{2}{|c|}{ N5 (5) } & \multicolumn{2}{|c|}{ PZ3 (8) } & \multicolumn{2}{|c|}{$\mathrm{M} 2(10)$} & \multicolumn{2}{|c|}{ PL4 (15) } & \multicolumn{2}{|c|}{ PL5 (16) } & \multicolumn{2}{|c|}{ PL10 (21) } \\
\hline & $N$ & $\%$ & $N$ & $\%$ & $\mathrm{~N}$ & $\%$ & $\mathrm{~N}$ & $\%$ & $N$ & $\%$ & $N$ & $\%$ & $\mathrm{~N}$ & $\%$ \\
\hline 1 & 0 & $(0)$ & 0 & $(0)$ & 15 & $(60)$ & 14 & (56) & 15 & $(60)$ & 21 & (84) & 22 & (88) \\
\hline 2 & 0 & (0) & 0 & (0) & 7 & (28) & 7 & (28) & 7 & (28) & 11 & (44) & 8 & (32) \\
\hline 3 & 0 & (0) & 0 & (0) & 2 & (8) & 2 & (8) & 1 & (4) & 8 & (32) & 1 & (4) \\
\hline 4 & 0 & (0) & 0 & (0) & 1 & (4) & 2 & (8) & 0 & $(0)$ & 6 & (24) & 1 & (4) \\
\hline 5 & 0 & (0) & 0 & (0) & 0 & (0) & 0 & (0) & 0 & (0) & 1 & (4) & 1 & (4) \\
\hline 6 & 0 & (0) & 0 & (0) & 0 & (0) & 0 & $(0)$ & 0 & (0) & 0 & (0) & 0 & (0) \\
\hline 7 & 0 & (0) & 0 & (0) & 0 & (0) & $-{ }^{a}$ & $--^{a}$ & 0 & (0) & 0 & (0) & 0 & $(0)$ \\
\hline 8 & 0 & (0) & 0 & (0) & 0 & (0) & & & 0 & (0) & 0 & (0) & 0 & $(0)$ \\
\hline 9 & 0 & 101 & 0 & 101 & 0 & ro & & & $n$ & (n) & 0 & (0) & 0 & (0) \\
\hline 10 & 0 & (0) & 0 & (0) & 0 & (0) & & & 0 & (0) & 0 & (0) & 0 & (0) \\
\hline 17 & 0 & (0) & 0 & (0) & 0 & (0) & & & 0 & (0) & 0 & (0) & 0 & (0) \\
\hline 24 & 0 & (0) & 0 & (0) & 0 & (0) & & & 0 & (0) & 0 & (0) & 0 & (0) \\
\hline 31 & 0 & (0) & 0 & (0) & 0 & (0) & & & 0 & (0) & 0 & (0) & 0 & (0) \\
\hline 38 & & & & & & & & & 0 & (0) & & & & \\
\hline 45 & & & & & & & & & 0 & (0) & & & & \\
\hline 52 & & & & & & & & & 0 & (0) & & & & \\
\hline 59 & & & & & & & & & 0 & (0) & & & & \\
\hline 66 & & & & & & & & & 0 & (0) & & & & \\
\hline 73 & & & & & & & & & 0 & (0) & & & & \\
\hline 80 & & & & & & & & & 0 & (0) & & & & \\
\hline 86 & & & & & & & & & 0 & (0) & & & & \\
\hline
\end{tabular}

other groups of postlarvae (initially 16 and $21 \mathrm{~d}$ old) were heavily infected with gregarines upon receipt from the Texas facility, with intensities of $>50$ gamonts per infected shrimp $(\mathrm{N}=10)$. The prevalence of infection in these groups declined from 84 and $88 \%$ respectively to $0 \%$ within $5 \mathrm{~d}$. Of those specimens sent to TAES, none of the nauplii and $<1 \%$ of the 1131 immediately fixed postlarvae ( $21 \mathrm{~d}$ old) exhibited the gregarine.

Prevalence of infection depended on method of treatment of infected shrimp. For example, when postlarvae (PL4) were received at GCRL on 4 May, they had been chilled to 17 to $18^{\circ} \mathrm{C}$ at the Texas production facility and received at $23^{\circ} \mathrm{C}$. They had been considered by the shipper to be heavily infected, but we determined the prevalence of infection at $38 \%$. On 28 May, shrimp left the Texas facility at 27 to $28^{\circ} \mathrm{C}$ and were received at $27^{\circ} \mathrm{C}$ with a $81 \%$ prevalence value.

Gregarine-infected shrimp maintained at GCRL lost their infection during holding; gamonts were voided from the gut. Six isolated postlarvae of Penaeus vannamei were infected with gamonts when examined at 12 and $22 \mathrm{~h}$ after receipt. These same individuals were examined again at $25 \mathrm{~h}$, and 5 were uninfected. Con- tents of the dish showed no free gamonts. The last infected shrimp, when monitored at 15 min intervals, showed a group of 5 gamonts located in the midgut adjacent to the hepatopancreas at $25 \mathrm{~h}$. By $27 \mathrm{~h}$, these gamonts could be seen immediately anterior to the hindgut, and at $28.5 \mathrm{~h}$ they passed out of the hindgut into the dish. The gamonts moved around for $10 \mathrm{~min}$ in the seawater before beginning to disintegrate (Fig. 4). However, mechanically removed gamonts placed in saline readily survived for at least $2 \mathrm{~h}$.

\section{Pathology}

There was no evidence of tissue degeneration or lesions in the gut of any gregarine-infected shrimp. The midgut epithelium appeared normal, and the microvillous border was clearly intact (Fig. 3). In postlarvae (16 and $21 \mathrm{~d}$ old) heavily infected with gamonts, histological sections revealed immature and mature gamonts attached to the microvillous border of epithelial cells (Fig 3). The mucron of some individuals was folded and thickened at the parasite-host cell interphase but did not penetrate the host cell. Many gamonts occurred free in the lumen. 
Table 2. Effect of various coccidiostats on infection with Paraophioidina scolecoides in postlarvae of Penaeus vannamei. Elancoban-100 $0^{\otimes}$ and Monteban ${ }^{*}$ (Elanco Animal Health); Rofenaid $40 S^{(y)}$ Medicated Mix and Bovatec ${ }^{(\omega)}$ Premix (Hoffmann-La Roche, Inc.)

\begin{tabular}{|lccc|}
\cline { 3 - 4 } $\begin{array}{c}\text { Treatment } \\
\text { group }\end{array}$ & $\begin{array}{c}\text { No. } \\
\text { examined }\end{array}$ & $\begin{array}{c}\text { No. } \\
\text { infected }\end{array}$ & $\begin{array}{c}\% \\
\text { infected }\end{array}$ \\
\hline Control & 76 & 12 & 15.8 \\
Rofenaid & 57 & 5 & 8.8 \\
Elancoban-100 & 50 & 1 & 2 \\
Bovatec & 56 & 5 & 8.9 \\
Monteban & 64 & 8 & 12.5 \\
Total & 303 & 31 & 10.2 \\
\hline
\end{tabular}

\section{Source of gregarine infection}

We were unable to determine the source of the gregarine infection. Gamonts were not observed in postlarvae from the 3 tanks in which we administered potentially infectious feces, maturation detritus or detritus associated with larval rearing. The control group was also uninfected over the $32 \mathrm{~d}$ experiment.

Gamonts or other stages were not noted from the midgut, hindgut or other tissues of the 2 male broodstock examined at GCRL or of the 5 examined at the facility. Also, we observed no gamonts or suspect stages either in dissections or squash preparations of 27 assorted invertebrates (belonging to 9 taxa) from the several sites at the facility or in detritus and water from those sites.

\section{Treatment}

No efficacy was noted for any of the 4 coccidiostats tested (Table 2). The infection was not eliminated in any of the test groups, and no statistically significant differences were detected among the treatments (chisquare test, $p>0.05$ ).

\section{DISCUSSION}

This new species is the first record of an aseptate gregarine from a penaeid shrimp. Previous reports of gregarines from cultured shrimp in North, South and Central America have involved members of the septate genera Nematopsis and Cephalobus (see Overstreet 1973, Lotz \& Overstreet 1990). We have seen large numbers of gamonts and gametocysts of a different gregarine, probably a member of the genus Nematopsis, in the midgut and hindgut of Penaeus vannamei from a commercial facility in Panama, although its life history has not been elucidated. Lightner (1993) reported sporozoites, gamonts, and gametocysts of Nematopsis sp. from pond-reared $P$. vannamei in Ecuador. In that case, the infection was managed by removing from the system the intermediate host, the polychaete Polydora cirrhosa, which had been a common inhabitant of the ponds.

Shrimp at the Texas facility acquired Paraophioidina scolecoides in larval rearing tanks when in their second protozoeal stage, and thereafter they remained infected throughout the larval rearing process. In contrast, infections were not maintained in shrimp received from Texas and reared at GCRL. These shrimp apparently purged their infection and never became reinfected. These observations were corroborated by the lack of infections in nauplii and low infection in $21 \mathrm{~d}$ old postlarvae sent to TAES

In the Texas facility, the infective stage was being continually introduced or available in the rearing tanks with incoming water. The gregarine may have been cycling within the larval rearing tanks but probably was not forming infective spores in the penaeid. Because disappearance of the infection occurred only after the larval rearing system was dried and cleaned, the gregarine seemed to have established itself in those rearing tanks. However, our inability to experimentally infect shrimp with detritus and water from the larval rearing tanks suggests a complicated life cycle, an inconspicuous host, or a seasonal nature of the infective stage.

We suggest that infection in larval and postlarval shrimp did not originate from the broodstock at the Texas facility because attempts to link infection with exposure to broodstock feces or to detritus from maturation tanks were unsuccessful. In addition, neither facility staff nor our investigations could demonstrate the gregarine in broodstock of Penaeus vannamei.

Our survey of the facility environment failed to find any invertebrates other than Penaeus vannamei that were infected with the gregarine. Our observations, however, did not encompass the total invertebrate fauna present in or near the facility, so additional sampling may help determine the life history.

We were unable to elucidate the life cycle of Paraophioidina scolecoides in Penaeus vannamei. We did not observe any stages other than gamonts in the midgut or hindgut of shrimp at either the Texas facility or GCRL. With the exception of the report on P. copiliae (Rose, 1933) by Rose (1933), intraepithelial stages have not been reported for other members of Paraophioidina. All development of $P$. scolecoides may occur entirely within the gut lumen as has been reported for some related species of Lecudina (see Shrével \& Philippe 1993). Gametocysts were reported by Jones (1968) for P. oaklandi (Jones, 1968), but 
Levine (1977), apparently unaware of her report, stated that gametocysts were not known from the group. Failure to discern gametocysts in $P$. scolecoides suggests that the life cycle of the gregarine is not completed within the shrimp. This lack of developed gametocysts, coupled with a short duration of infection and release of living gamonts from the gut with their subsequent disintegration in seawater, supports the hypothesis that $P$. vannamei is not a suitable host to complete the life cycle of $P$. scolecoides. $P$. vannamei probably serves as an accidental host, accepting the infective stage meant for another invertebrate, most likely another crustacean like the hosts for other members of Paraophioidina.

Usually gregarines are not associated with poor shrimp health. However, Lightner (1993) reported that pond-reared shrimp heavily infected with Nematopsis sp. exhibited a yellowish discoloration of the midgut and a susceptibility to potentially lethal secondary bacterial infections. Such infections in shrimp caused reduction, perforation and hyperplasia of the midgut epithelium. Furthermore, he concluded that heavy gregarine infections may potentially cause economic losses by reducing growth and causing mortality of the shrimp stock. At the Texas facility, abnormal growth or mortality rates of the penaeid in grow-out ponds stocked with infected postlarvae were not noted. In addition, we saw no gross pathological changes in even the most heavily infected postlarvae. The parasite apparently is unable to reproduce in the shrimp or lacks an intraepithelial developmental stage, a potential cause of host tissue damage and cell destruction for some species. The attachment of gamonts of Paraophioidina scolecoides to the gut epithelium did not affect the host. Shrével \& Philippe (1993) reported that gamonts of a species of Lecudina attaching to the gut epithelium of the host caused modification or degeneration of host tissues at the site of attachment. The gamont of $P$. scolecoides probably uses the mucron both to combat peristalsis and to maintain its position in the shrimp's midgut, rather than for absorption.

Although we found little evidence of pathologic alterations, there may be more subtle economic ramifications from infections with Paraophioidina scolecoides. Because this was a previously unrecognized parasite of Penaeus vannamei, potential buyers of seed may be reluctant to buy and regulators may be reluctant to allow transportation of infected seed.

The preliminary study on drug treatments was included in this paper because we thought the information would be helpful to researchers and commercial parties. Some confidential, unpublished studies with poultry or cattle dose-levels of anti-coccidian compounds in feeds have shown some promise in gregarine-infected, pond-reared shrimp in Ecuador (Bell
\& Lightner 1992, Lightner 1993). Our results indicate that at least Elancoban-100 is worthy of additional testing and that some medicated feeds may not have as good a prospect for short-term treatment of infected stocks as other anti-coccidian compounds. The reason that the controls had the relatively high prevalence of $16 \%$ after 6 d may relate to continuous maintenance of shrimp at relatively high temperatures, immediate shipment of infected shrimp from the facility, different genetic groups of shrimp, or other factors. In some cases, shrimp took $2 \mathrm{~d}$ for shipment from Texas to GCRL. Reducing the temperature of shrimp for shipment, a common practice used to avoid stress during transport, appears to reduce the gregarine infections.

Arknowledgements We thank the staff at the Texas facility for their assistance in providing valuable information and materials as well as shipping infected shrimp to Mississippi. We thank Marie Wright, Susan Powell, and Jean JovonovichAlvillar for their excellent technical assistance, Addison Lawrence for his assistance in the drug study, and Sergio Bellver for his translation of French and Italian articles. This study was conducted with the cooperation of the U.S. Department of Agriculture CSRS Grant No. 92-8808-6920.

\section{LITERATURE CITED}

Bell, T. A., Lightner, D.V. (1992). Chemotherapy in aquaculture today - current practices in shrimp culture: available treatments and their efficacy. In: Michel, C., Alderman, D. J. (eds.) Chemotherapy in aquaculture: from theory to reality. International Office of Epizootics, Paris, p. 45-57

Hildebrand, H. F., Vinckier, D. (1975). Nouvelles observations sur la grégarine Didymophyes gigantea Stein. J. Protozool. 22: 200-213

Humason, G. L. (1972). Animal tissue techniques, 3rd edn. W. H. Freeman \& Co., San Francisco

Jones, I. (1968). The life cycle of Ganymedes oaklandi n. sp., an acephaline greganine of Gammarus fasciatus (Say). J. Protozool. 15: 414-418

Kruse, D. N. (1959). Parasites of the commercial shrimps Penaeus aztecus lves, $P$. duorarum Burkenroad and $P$. setiferus (Linnaeus). Tulane Stud. Zool. 7: 123-144

Levine, N. D. (1976). Revision and checklist of the species of the aseptate gregarine genus Lecudina. Trans. Am. Microsc. Soc. 95: 695-702

Levine, N. D. (1977). Revision and checklist of the species (other than Lecudina) of the aseptate gregarine family Lecudinidae. J. Protozool. 24: 41-52

Lightner, D. V. (1993). Diseases of cultured penaeid shrimp In: McVey, J. P. (ed.) Handbook of mariculture, Vol. I, Crustacean aquaculture, 2nd edn. CRC Press, Boca Raton, p. 393-485

Lotz, J. M., Overstreet, R. M. (1990). Parasites and predators. In: Chavez, J. C., Sosa, N. O. (eds.) The aquaculture of shrimp, prawn and crawfish in the world: basics and technologies. Midori Shobo Co. Ltd., Ikebukuro, Toshima-ku Tokyo, p. 96-121 (in Japanese)

Manwell, R. D. (1977). Gregarines and haemogregarines. In: Kreier, J. P. (ed.) Parasitic Protozoa, Vol. III. Academic Press, New York, p. 1-29

Overstreet, R. M. (1973). Parasites of some penaeid shrimps with emphasis on reared hosts. Aquaculture 2: 105-140 
Rose, M. (1933). Monocystis copiliae n. sp.; grégarine parasite d'un copépode pélagique: Copilia vitrea, Haeckel. Bull. Soc. Hist. nat. Afrique Nord 24: 357-359

Shrével, J. (1971). Observations biologiques et ultrastructurales sur les Selenidiidae et leurs conséquences sur la systématique des grégarinomorphes. J. Protozool. 18: $448-470$

Shrével, J., Philippe, M. (1993). The gregarines. In: Kreier, J. (ed.) Parasitic Protozoa, Vol. IV, 2nd edn. Academic Press, New York, p. 133-245

Responsible Subject Editor: J. E. Stewart, Dartmouth, N.S., Canada
Théodoridès, J., Desportes, I. (1972). Mise en évidence de nouveaux représentants de la famille Ganymededidae Huxley, grégarines parasites de crustacés. C.I. Acad. Sci. Sér. D 274: 3251-3253

Théodoridès, J., Desportes, I. (1975). Sporozoaires d'invertébrés pélagiques de Villefranche-sur-Mer (étude descriptive et faunistique). Protistologica 11: 205-220

Wilkinson, L., Hill, M., Welna, J. P., Birkenbeuel, G. K. (1992). SYSTAT for Windows: statistics, 5 edn. SYSTAT, Inc., Evanston, IL

Manuscript first received: December 21, 1993

Revised version accepted: March 6, 1994 